As chairman of the committee on policy and program you were instrumental in establishing, from the 58 year old public-service Canadian Forestry Association, the present well-planned Federation of autonomous, provincial forestry associations.

As chairman of the first National Forest Fire Research Conference and of the three subsequent conferences you have stimulated interest, concentrated effort and directed investigation toward improved methods of preventing and of suppressing fires in the forests of Canada.

For your outstanding contributions to the advancement of the practice of forestry, for your dedicated effort in behalf of more effective forest fire protection, for your strong character and high integrity in your profession.

The Canadian Forestry Association is honoured on this occasion to present to you its 1961 Forest Conservation Award."

\title{
General Activities of the National Office
}

Apart from the general routine of the Institute, there has been heavy correspondence on the recent joint S.A.F.-C.I.F. meeting-and again more students inside and outside of Canada inquiring on the profession of forestry in Canada. With our president, Mr. Besley, we are in the process of re-organizing and helping the many C.I.F. National committees. The Secretary-Manager recently attended two Section meetings and two National meetings.

The dues receipts and the second dues notices have been sent. The Certificates are being prepared for over 300 members who requested them. The revised Section lists of members are sent to the 20 different sections. Material, ads, etc., were sent for this December issue of the Chronicle, and many libraries were supplied with back issues of the Chronicle, as requested. The Insurance Company will send another mailing to all members on the Life Insurance Plan and the Group Pension Plan.

Over 50 new applications for membership were received, and only 9 resigned (of which 7 were retired from their work).

J. J. E. Dosne

\section{NEWS OF THE SECTIONS}

\section{NEWFOUNDLAND}

Well, I have found out one thing and that is that at least two of our Section members read my periodic submissions to The Chronicle. This became known to me when my news for the September issue was conspicuous by its absence.

For these as well as others who may wonder "wot happened" the truth of the matter is that there was just nothing to report and this is what was passed along to the edtior.

Sad to say my contribution at this time could well be summed up in a like manner. As those in the Section know, we had planned to hold a field meeting this past summer and this would have been my main contribution for this issue. However, the meeting after one postponement had to be cancelled for the year due to the critical forest fire situation which prevailed in the 
Province for practically all the summer, and which tied down many of our members and prevented them from attending the meeting. For those who might be interested we hope to hold this meeting in the early summer of 1962 .

Currently, plans are well in hand for the annual meeting to take place in Corner Brook the latter part of November. It will be over when this is read and will be fully reported upon in the March issue.

Personnel news is likewise scarce. Two new members are welcomed to the Section in the persons of Joe Lowe and Gary Saunders. Joe is with the Provincial Forest Service while Gary is Forestry lecturer at Memorial University.

At least three of our members, Bill Johnston, Don Nickerson and Max Vardy attended the Annual Meeting in Minneapolis. Several others were present at the recent Resources for Tomorrow Conference in Montreal.

W. A. DICKson

\section{Nova Scotia}

Members of the Nova Scotia Section attending the "Resources for Tomorrow" Conference, at Montreal October 23-28, were E. S. Atkins, J. R. Bigelow, R. H. Burgess, G. W. I. Creighton, L. S. Hawboldt, Leif Holt and R. S. Johnson. "Survey and Assessment of Forest Management Practices on Private Lands" by R. S. Johnson and Leif Holt was one of nine background papers on forestry considered at this conference.

Murray Anderson and Windsor Kelly of Nova Scotia Pulp Limited, have recently returned from a six weeks' visit to Sweden where they observed forest management practices.

In the past year 11 Tree Farms comprising 22,240 acres have been certified in Nova Scotia by the committee of which R. R. Murray is chairman. This committee operates under the Canadian Forestry Association of Nova Scotia.

R. S. JOHNSON

\section{MARITIME}

The 25th Annual Meeting of the Maritime Section was held at the Entomological Laboratory near the Summit Depot of Fraser Companies Ltd., 40 miles north of Edmundston, N.B. The facilities of the Forest Research Branch of the Department of Forestry were used by the Section members. The latest developments in forest research and applied silviculture were studied on field trips. This is the base for research projects including management and protection, problems connected with recurring spruce budworm attack, and recently, growth and yield, logging and utilization studies. The laboratory is under the joint sponsorship of the Federal and Provincial Governments and Fraser Companies Ltd.

Of the fifty-five attending, nine were charter members, and had been active in the Section since its formation in 1936. These were V. C. Bastin, L. D. Black, B. W. Fleiger, H. D. Heaney, E. L. Howie, D. W. W. Hudson, G. L. Miller, L. S. Webb and D. A. Wolstenholme. 
The Institute gold medal was presented by E. S. Fellows, director, to H. T. Boyles, the University of New Brunswick forestry graduate having the highest class standing in 1961. Mr. Boyles is employed by Fraser Companies Ltd.

Fraser Companies Ltd. President Aubrey Crabtree was guest speaker at the banquet. Mr. Crabtree, speaking on production costs of pulp and paper, said that foresters must keep a close vigilance on costs. He also stressed the importance of being fully informed on the latest advances in the science of forestry and suggested that foresters could best do this by reading all available trade journals, research papers, etc., pertaining to their field.

The Section has been interested for some time in the possibilities of radar for tracking electrical storms as an aid in forest fire control. The meeting went on record as being in support of the establishment of a weather radar station in the Province which would tie in with existing radar installations.

The meeting ended with a tour of the Fraser Companies Ltd. pulp mill in Edmundston, N.B. and the paper mill in Madawaska, Maine, U.S.A. where the pulp, pumped across by pipeline from the Canadian side of the border, is manufactured into finished paper products.

The C.I.F.-.S.A.F. Joint Annual Meeting in Minneapolis was attended by seven section members: E. S. Fellows, Dr. R. E. Balch, Dr. J. W. Ker, L. R. Seheult, B. C. Wile, L. G. Davis and B. Post.

Dr. R. E. Balch, who retired recently as Officer-in-Charge of the Forest Biology Laboratory of the Department of Forestry in Fredericton, was presented with an award by the Society of American Foresters at the annual dinner on October $11 \mathrm{th}$. The award consisted of an engraved plaque and a cheque presented in recognition of "outstanding achievement in biological research contributing to the advancement of forestry." Dr. Balch is continuing full-time research at the laboratory. The award was instituted in 1956 and this is the first time that it has been given to a Canadian. Dr. Balch was President of the national body of the Institute in 1949 and 1950.

W. W. McCormack, who recently retired as Deputy Minister of the New Brunswick Department of Lands and Mines, was elected an Honorary Member of the Institute at the Annual Meeting.

Dr. J. W. Ker delivered a paper entitled "Canadian Experience with the Five-year Undergraduate Forestry Curriculum."

L. R. Seheult presented a paper on "Significant Trends and Problems in Timber Harvesting in Eastern Canada."

A. L. VanSlyke was appointed to act on the Committee on Forest Mensuration Course Syllabi, a joint C.I.F.-S.A.F. project.

A number of Section members took an active part in a special meeting for representatives of the press, radio, television, and members of the Government. The meeting was arranged by the New Brunswick Branch of the Forest Products Association and held in Bathurst on October 17, 1961, during National Forest Products Week October 15-21. Dr. J. W. Ker, V. C. Bastin, J. H. Ferris, D. McLaren and G. C. Cunningham took part in the program.

The Section was ably represented among the provincial representatives to the Resources for Tomorrow Conference. K. B. Brown, Deputy Minister 
and R. L. Bishop, Executive Assistant, New Brunswick Department of Lands and Mines; E. S. Fellows, Consulting Forester and C.I.F. Director; Bruce S. Wright, Director, Northeastern Wildlife Station; B. W. Flieger, Manager, Forest Protection Ltd.; R. S. Johnson, Forester, Mersey Paper Co. N.S., and Dr. J. Miles Gibson who was Chairman of Technical Committee "B".

University of New Brunswick Forestry Faculty News Representative, Dennis Schafer, a Senior, provided some interesting items.

N. L. Kissick succeeded Dr. S. L. Pringle, now with the U.N. in Rome, as Professor of Forest Management. Professor Kissick is a graduate of the University of Toronto where he obtained his B.Sc.F., and has an M.Sc.F. from Yale. Before coming to U.N.B. he managed the University of Toronto forest at Dorset. He has now transferred his membership from the Toronto Section.

G. R. Powell, a new member of the Institute and Section, is a graduate in Forestry from Edinburgh University. He has been doing post-graduate work at U.N.B. and has agreed to stay for a year as lecturer in Forest Ecology.

E. W. Roberts, "Doc" to those of us who knew him for his very lucid explanations of the deep secrets of Photogrammetry and Topographic Surveying as a member of the U.N.B. Forestry Faculty from 1948-52, has been appointed Secretary of the U.N.B. Associated Alumni. "Doc" is a graduate of U.N.B. and Syracuse, N.Y., and, before taking up his new position in October this year, was Manager of $\mathbf{J}$. W. Sewall Co. (Canada) Ltd. in Fredericton.

Dr. E. G. Hagmeier, Professor of Plant Ecology in the Department of Biology at U.N.B., has transferred to the Victoria Section. Dr. Hagmeier is a graduate of Queens and took his M.A. and Doctorate at U.B.C. $\mathrm{He}$ is joining the staff of Victoria College, Victoria, B.C.

Student enrollment in the five-year Forestry Course this year totals 245, the highest figure since the post-war peak.

U.N.B. Forestry Association Annual Forestry Week was held October 16-21. Events included a soccer game with the Engineers, social evening, inter-class tug-o-war, water polo match with coeds from the ladies' residence and the HAMMERFEST. Joe Trevors, from Douglasfield, N.B. emerged from the melee as "BULL OF THE WOODS."

Janet Maybee, daughter of Gordon R. Maybee, Forestry '50, and a pretty Nova Scotian from Truro, was chosen "Queen of the Bushman's Ball."

The Second Annual Forestry Yearbook, "THE LEADER" will be available November 10, 1961. Graduates may obtain a copy by sending $\$ 1.00$ to: The Secretary, Yearbook Committee, U.N.B. Forestry Association, University of New Brunswick, Fredericton.

L. G. Davis, Superintendent, Department of Forestry, Camp Gagetown, spent several weeks on the Dunn River fire in Newfoundland this summer.

D. O. Greenbank, B.Sc.F. '50 and M.Sc.F. '53, U.N.B., has joined the Maritime Section. Dave is working on Spruce Budworm research at the Forest Biology Laboratory in Fredericton. 
Peter M. Paul has transferred from the Ottawa Valley Section. He is working on forest fire research in the Maritime Provinces.

A. Jablanczy, formerly a professor in forestry at the Sopron Division of the University of British Columbia has transferred to the Maritime Section. $\mathrm{He}$ is a Silviculturalist and is working with the Forest Research Branch of the Department of Forestry in Fredericton.

"THE J. MILES GIBSON SCHOLARSHIP FUND." J. Ian MacDonald, Treasurer of the Fund, wishes to ask all those who have known Dr. Gibson, and, particularly, foresters who graduated from U.N.B. under his guidance, to make their contributions to the Fund as soon as possible. Out of approximately seven hundred and fifty graduates, who were advised of the formation of the Fund, only one third have contributed to date. The amount received, which includes donations from six pulp and paper companies, has not yet reached half of the goal of $\$ 10,000$. Any donations large or small will be welcome. Make yours in an amount commensurate with your indebtedness to Dr. Gibson for your present success in your profession, and help a future forester to join you as a member of the Institute.

\section{Quebec}

JoHN P. FrancIS

In September, regional meetings were held in Montreal, Quebec and Grand'Mere, with dinner preceding the gatherings at the latter two locations. After brief business sessions, series of panelists debated topical forestry questions dealing chiefly with the profession and its leadership, silviculture and modern logging, forest protection and matters of recreation. With all present participating in the discussions, the exchanges were lively and informative. A further series of such meetings is planned for the immediate future.

Several recent and noteworthy events occasioned much activity among various segments of the membership. Dr. Andre Linteau chaired the Northeastern Forest Soils Conference, convened this year in Quebec. G. J. (Guy) Lemieux, M. L. G. (Michel) Jurdant and R. J. (Bob) Hatcher directed a round of stimulating field trips for the large body of soils men in attendance. Guy Lemieux and H. S. D. (Stewart) Swan are now members respectively of the Site Evaluation Committee and the Forest Nursery Soil Improvement Committee of the Conference.

Drs. A. Linteau and L. Rousseau, Bob Hatcher and Guy Lemieux had an interesting trip through Quebec woods with Prof. Josef Koestler and Dr. G. Sommers, Foresters from the University of Munich, Germany.

Lucien Bedard is gradually surfacing after the deluge of success which hit the Eastern Townships Forestry Association Convention at which Ernest Dupuis was elected an Honorary Director. W. A. E. Pepler, Lowell Besley and F. A. Harrison rolled up shirt sleeves on the Forestry Advisory Group of the "Resources of Tomorrow" Conference held in Montreal.

Our section welcomes a new member in Dr. G. L. Lowry who has joined the staff of the P.P.R.I.C. as Forester (Forest Soils) in the Woodlands Research Department.

Congratulations to Louis C. O'Neill and J. M. McLeod, who recently received doctorates in Entomology from the New York State College of 
Forestry, Syracuse. Both work for the Biology Division of the Quebec Forest Research Laboratory, Canada Department of Forestry.

Good luck to Michel Jurdant of the same laboratory, who is currently on leave to prepare a doctorate in forest soils at Cornell.

\section{September}

\section{AlgonQuiN}

J. M. Conway

The September meeting of the Algonquin Section was held in Chalk River on September 15. During the afternoon, members of the Section, wives and guests were conducted on a tour of the Atomic Energy Company Limited plant. Highlight of the afternoon's activities was the very interesting and informative introduction to the principles and uses of Atomic energy given by Dr. David A. Keyes, Scientific Advisor to the President of A.E.C.L. Following the tour, while a short business meeting was being held at the Petawawa Forest Experiment Station, the wives and guests were shown films of various forestry activities.

The day's activities were brought to a close with an excellent turkey dinner served in the dining room of the Petawawa Forest Experiment Station. October

The October meeting of the Algonquin Section was held in Pembroke on October 18th.

As part of National Forest Products week, members of the Section and their guests toured the Canada Veneers plant in Pembroke. Under the personal direction of Mr. A. MeNair, General Manager of the Company, the group was given a clear insight into the mechanics of yellow birch manufacture.

Following the tour the group met at the Northwood Hotel for dinner and a business meeting.

The after dinner address was given by Messrs J. W. Slacke and E. H. Jacques, trade promotion specialists with the White Pine Bureau of the Canadian Lumbermen's Association. They spoke on the importance of Forestry in Canada's economy, and White Pine in our local economy-ably illustrated with colour slides and a sound and colour film comparing the heat resistance and load capacities of wooden and steel beams carrying equivalent loads. The superior qualities of the wooden beams were graphically illustrated.

We are indebted to the Canada Veneers and Messrs. Slacke and Jacques for their contribution to a very interesting and informative day.

\section{NORTHERN ONTARIO}

R. JohN HALL

The winter season started with a meeting at Iroquois Falls, where the Honourable J. W. Spooner, Ontario Minister of Lands and Forests, addressed the section on forestry in Europe, with emphasis on Scandinavia and Russia. Mr. Spooner was accompanied by Mr. G. H. Bayly, Assistant Deputy Minister of the Department of Lands and Forests, who also accompanied him on his European trip.

Mr. Spooner's remarks should shake us out of any complacency regarding the position of our industry in the world, particularly when Russia 
develops a pulp and paper industry large enough to compete strongly over most of the world.

Research in the Section, particularly within the Clay Belt, seems to have accelerated this past season. Several scientists visited the area, starting with A. B. Vincent of the Federal Forestry Department who is instituting a study of clay belt black spruce.

Later A. P. Leslie and Professor T. W. Dwight of the Ontario Department of Lands and Forests were here in connection with a scaling research project. Then we were visited by a group of scientists from Federal and Provincial Governments and the U.S. Department of Agriculture, Forest Service on a clay soils study. The American visitors were Dr. M. L. Heinselman, John Benzie, and Wm. Johnston.

Several members were lost to the Section this past season, including J. C. Burch, A. Z. Michalowicz, F. T. Lewiecki and W. A. Montgomery, all of Smooth Rock Falls. F. N. Robinson was transferred from Smooth Rock Falls to Iroquois Falls

A. E. Davis, Woodlands Construction Engineer of the Spruce Falls Power and Paper Co. Ltd., Kapuskasing, Ontario has been appointed Assistant to the General Sales Manager of the above company. Ed expects to move to Toronto in November to start his new duties.

R. A. Baxter, of the Ontario Department of Lands and Forests, Kapuskasing is presently taking the Resources Management Course at the University of Toronto.

F. N. RoBINSON

\section{SOUTHERN ONTARIO}

The first meeting of the 1961-62 season was held in October and was addressed by Mr. G. H. Bayly, Assistant Deputy Minister, Ontario Department of Lands and Forests. Mr. Bayly returned recently from a fact-finding tour of several northern European countries, including Russia. $\mathrm{He}$ gave his observations on both social and forestry aspects of the countries visited, illustrating his talk with some excellent movies.

For the second consecutive year this section took part in the career exposition for high school students arranged by the Galt and District Y's Men's Club. This is a project where information on careers is offered "cafeteria style". Booths were erected by the club in the Galt Armouries and representatives from the professions, universities and other educational institutions, the armed services, other government services, and a number of trades were invited to install and man suitable exhibits designed to interest the students in their own future vocations.

Twenty secondary schools from the surrounding communities were invited to participate by bringing their students according to a pre-arranged schedule. Morning and afternoon periods were arranged for scheduled group visits for three days commencing October 24th. In the evenings, parents and students who were unable to come during the day were invited.

In 1960, 4,200 students attended the daytime sessions and an estimated 2,500 persons came to view the exhibits during the three evening sessions. 
To judge by the continuous flow of student groups, this year a similarly successful attendance was indicated.

Foresters from the Southern Ontario Section, representing the forest industries, the Faculty of Forestry, the Ontario Forestry Association, conservation authorities and the Ontario Department of Lands and Forests, helped man the booths. The cooperation of District Forester Ellis Dreyer and his staff was especially appreciated in setting up the exhibit.

Those who manned the exhibit reported a steady stream of interested students with questions ranging over the whole field of forestry and related subjects.

F. M. BUCKINGHAM

\section{Central Ontario}

The Central Ontario Section held a fall meeting at Espanola on September 22nd and 23rd. The program on the 22nd included an afternoon field trip to study poplar management. Poplar cuts on different sites were visited, with special attention being paid to soil pits, regeneration, and management requirements. A number of interesting points arose at each location and considerable discussion resulted.

This poplar field trip was organized by Jack Flowers and Bill Maslen, both of whom are to be congratulated on providing a very worthwhile afternoon program. Some weeks prior to the meeting Jack Flowers produced and distributed a five-page report entitled "Some Facts About Poplar". This was a comprehensive review dealing with poplar management and it summarized available information very well.

Following the afternoon's activities there was a social hour and dinner at the Espanola Hotel. A good crowd, with ladies included, enjoyed the occasion. Later in the evening Mr. and Mrs. J. W. Tate of Sudbury showed slides of their recent world tour. Both the slides and the commentary were of unusual interest and much appreciated.

A business meeting was held on the morning of September 23rd. A number of committee reports not dealt with at the Section's annual meeting received attention. Various suggestions were made concerning coming events and Section activity. Matters concerning the C.I.F. annual meeting were also discussed.

\section{NORTHWESTERN ONTARIO}

G. R. MORRISON

At least fifteen members of our Section attended the Annual meeting at Minneapolis in October.

Mr. J. H. Merrill, Vice-President in charge of Woodlands for the Great Lakes Paper Co. retired as of October 31st.

In mid September N. F. Lyon, Ontario Department of Lands and Forests, Port Arthur, left to undertake a year of post-graduate study at the University of Minnesota.

The Ontario Paper Company have moved Art Racey to Heron Bay in this section and moved Dennis Brophy from Heron Bay to their Manitoulin operations. Both men hold the position of plant forester. 
Recently, Ken McCron, District Superintendent, with Kimberly-Clark at Longlac has been given special duties connected with the employment and training of Indian workmen.

J. C. Day of Longlac has become a member of the Kimberly-Clark Quarter Century Club.

R. J. Julian left Caramat and the Marathon Corporation in September to attend the Ontario College of Education.

\section{LAKE OF THE WOODS}

R. S. HYSLOP

A business meeting was held in the Department of Lands and Forests office in Fort Frances on Saturday, November 11th.

H. A. Coles, chairman, appointed a nominating committee of $\mathbf{N}$. Golder (chairman), B. Seppala, and J. Blair.

F. E. Sider was appointed chairman of the membership committee as the former chairman, A. A. "Sandy" Russell of Dryden was recently transferred to St. Williams, Ont. Mr. Russell was active in C.I.F. affairs and will certainly be missed in this section.

R. S. M. Bunney, Section Representative, reported on the Board of Directors meeting held in Minneapolis, Minn.

B. Seppala gave a report on the interesting program offered at the joint annual meeting of the C.I.F. - S.A.F. in Minneapolis. Approximately $30 \%$ of the members of the Lake of the Woods Section attended this joint annual meeting.

A discussion followed these two reports.

The group was taken on a tour by water of the $31 / 2$-mile-long Rainy Lake Causeway at Fort Frances.

Fourteen members attended the meeting.

\section{MANITOBA}

W. F. BEATTY

The Manitoba Section was well represented at the combined C.I.F.S.A.F. meeting held in Minneapolis in October. At least 18 members were present which represents approximately 30 per cent of the Section's membership.

A council meeting was held at Rennie, Manitoba on August 29, 1961. Among topics discussed were the agenda for the Directors' meeting at Minneapolis and the publicity and education program of the Section.

A council meeting was scheduled to be held in Pine Falls on November 9,1961 , and the tentative date for the fall meeting was to be November 24 , 1961.

Two new members, H. P. (Percy) Sims and G. A. (Gus) Steneker, are welcomed to the Section. Both members are employed by the Forest Research Branch of the Dept. of Forestry. Percy is engaged in ecological studies of jack pine and Gus is working on the tending of aspen and white spruce stands.

J. H. CAYFoRD 


\section{Rocky MOUNTAIN}

The annual fall meeting was held on Sept. 22, 23 and 24 at Hinton. Mr. J. Dosne, and members of the Kootenay and Cariboo sections were in attendance. North West Pulp and Power Ltd., and the Provincial Forestry Training School acted as hosts, and provided a very interesting program and successful social meeting.

New innovations in forestry practice on the Hinton pulpwood lease were demonstrated. A tape recorder being used to record cruise data in the re-measurement of permanent sample plots has replaced one man on the field crew. The age of automation appears to be catching up with notekeepers at Hinton. A method of predicting spruce seed crops has been devised and is being used to help decide which areas should be scarified in the fall. Dragging a heavy boom chain behind the tractors has helped to even the distribution of slash on the scarified areas.

A woodlands tour demonstrated the various methods of skidding and loading being employed by the pulpwood contractors. The champagne luncheon provided by Mr. J. Drapeau and North West Pulp and Power was a much appreciated innovation to the itinerary of woods tours.

The Hon. Norman Wilmore, Minister of Lands and Forests, welcomed the guests Friday night at a dinner provided by his department at the new Forestry Training School. A lively social evening followed and gave the guests a chance to become re-acquainted.

Dr. D. R. Redmond, Director of Forest Research, Dept. of Forestry, addressed the banquet Saturday evening. The functions of the Dept. of Forestry were explained by Dr. Redmond along with some plans for future expansion of facilities and personnel.

Ted Curry and Walter Moore have recently transferred to this Section from the East.

\section{OKANAGAN}

Glen Paul

Eighteen members attended a meeting in Kamloops on Sept. 29. The need for total clearing prior to flooding was discussed again and after considerable debate the question of further action was tabled.

Members of the 1961-62 executive are: Chairman, Fred Stinson; Vice Chairman, H. Gavin; Secretary Treasurer, G. Boulton; Directors-N. McRae, H. Mason, and B. Hansen. Norm McRae is chairman of the Education Committee. Larry Parlow is chairman of the Membership Committee.

The meeting adjourned after an excellent talk by Doug Ross.

At a meeting at Vernon on October 27, a total of 21 members was present. The program for the balance of the winter was outlined to include meetings at monthly intervals to May.

An exceptionally interesting illustrated talk was given by Jim MacIntosh, Logging Specialist, employed by the Vancouver Forest Products Laboratory of the Federal Department of Forestry. Jim's discussion of his current project on correlations between tree quality and lumber quality and recovery prompted a lively discussion and many questions on the subject.

G. BoultoN 


\section{CARIBOO}

To complete the list of the Executive for the Cariboo Section that appeared in the last Chronicle, our Secretary-Treasurer is Bill Grainger and the News Representative is George Kondor.

A group of fifteen members of our section took a trip to Hinton, Alberta, for a joint meeting with the Rocky Mountain Section. They toured the operations of Northwestern Pulp and Power Ltd., hoping that what they saw will prove to be useful when the much talked about pulp mill will finally be built in this area.

The annual social meeting was held at the home of Harry and Marg Gairns, who kindly lent their home for the festivities.

A dinner meeting was planned for November 10th, at which our members will have the opportunity to get acquainted with the work of the Federal Department of Forestry in B.C., through our guest speaker Mr. L. A. (Bud) Smithers.

Harvey Anderson, who attended the joint meeting at Minneapolis was to give a short report on his trip at this meeting.

Carman Smith left this area for the Queen Charlotte Islands.

Of the three new foresters that arrived to this area, Larry Hope is employed by Eagle Lake Sawmills Ltd., Bill Batten by Northwood Mills Ltd., and Jack Milburn by Okanagan Helicopters Ltd.

GEORGE KONDOR

\section{VANCOUVER}

Ninety-two million people in Japan create a tremendous market for logs and lumber. Fifty members of the Vancouver Section learned at their first meeting of the desk-bound portion of the year on October 10, 1961, that B.C. is now taking advantage of the Japanese market in spite of handicaps.

Recently, the lumber market has grown from only 1,607,274 f.b.m. shipped from B.C. to Japan in 1960 to $84,662,275$ f.b.m. shipped in the first eight months of 1961, according to Pacific Lumber Inspection Bureau figures.

"Logs and lumber entering Japan from North America amounted to more than 400 million f.b.m. up to last August," said Ralph E. Smith, of ArnottSmith Timber Co. Ltd., Vancouver, B.C. "Japan's requirements are expected to be 600 million f.b.m. for the year."

Mr. Smith then listed the difficulties standing in the way of increased B.C. forest-products trade with Japan: (1) competition in soft-woods from other countries on the Pacific Ocean; (2) Canadian and B.C. laws discouraging the export of unmanufactured logs; (3) congestion in Japanese ports, causing slow turn-around time for ships; (4) the near impossibility of getting ships to pick up partial cargoes in B.C. ports; and (5) the B.C. Export Advisory Committee in which loggers have too little representation.

Second speaker at the meeting was Japanese economist Yashi Itami, who has been in Vancouver for four-and-a-half years with Mitsui and Co. Ltd. He said that Japanese government steps are being taken to relieve port congestion and that B.C. logs instead of lumber are preferred in Japan, to 
more easily meet shifts in the islands' lumber market that can't be predicted three or more months in advance-the trans-Pacific time required for lumber shipments from B.C.

Thus, about 70 per cent of the wood-products imported into Japan are logs. The logs are efficiently converted into lumber, Mr. Itami said, in the 38,000 sawmills on the islands, most of which have 22-gauge saws.

Both speakers pointed out that the U.S. exports to Japan are about ten times B.C.'s wood exports despite greater shipping costs.

General Chairman for the 1962 C.I.F. Annual Meeting, W. P. T. McGhee, has selected his committee chairmen for the event. As Assistant General Chairman he chose J. R. Collins, the current Chairman of the Vancouver Section.

Committees and their chairmen are as follows: Registration, W. Leesing; Program, G. R. Patterson; Finance, R. L. Caesar; Field Trips, W. B. Gayle; Publicity, Robert H. Forbes; Social Co-chairmen, Marc W. Gormely and Mrs. E. S. Reid; Advisory, Ian Cameron and Dr. B. G. Griffith; Special Preparations, W. F. Myring.

The chairmen held their first meeting November 1 in an effort to get the ball rolling for a successful Annual Meeting on the broad theme of "Forest Integration".

ROBERT H. FORBES

\section{VANCOUVER ISLAND}

The Shawnigan Division of MacMillan, Bloedel, and Powell River Ltd. was the host for the annual field day held on October fourteenth. The subject for the first Section get together of the season was "Slash Burning". I. K. Barber acted as tour leader and was moderator for the panel discussion which followed the field day. Panel members included K. Hallberg, F. Maber, C. Hadden, R. Foster, A. Bamford, and D. Williams. Sixty members attended and spent a very enjoyable sunny day, highlighted by a contest during which a 750-year-old Douglas fir tree was subjected to the scrutiny of expert cruisers. Glen Patterson and Alex Harper were the true experts on this occasion and received a free dinner for their estimates. The hospitality of Mr. and Mrs. G. Wellburn was enjoyed when a side trip was made to Gerry's logging museum.

Fifty section members enjoyed an illustrated talk given on November third at Duncan by Dr. Bruce Zobel. Dr. Zobel, a forest geneticist from Raleigh, North Carolina, indicated by his talk that forest genetics is no ivory tower dream and his practical approach was most refreshing. Especially interesting were his slides showing three-year-old grafts of loblolly pine which were bearing cones. The section is indebted to the PLUS TREE BOARD of the TREE FARM FORESTRY COMMITTEE for bringing Dr. Zobel to B.C.

BRUCE DEVITT 